Ann. Génét. Sél. anim., I975, 7 (4), 449-460.

\title{
INDIRECT SELECTION \\ IN POULTRY BREEDING WITH SPECIAL REFERENCE TO SINGLE GENES
}

\author{
P. MÉRAT \\ Laboratoire de Génétique factorielle, \\ Centre national de Recherches zootechniques, I. N. R. A., \\ 78350 Jouy en Josas
}

SUMMARY

The interest of indirect selection in poultry breeding is discussed, with special reference to the utilization of known genes. The most favourable situations are those where the intensity of direct selection is zero (trait impossible or too costly to measure, environment where the progress is desired difficult to realize, or presence of negative genetic correlations suppressing genetic gain) and that where the heritability of the trait to improve is low or zero (selection plateaux).

Examples corresponding to these situations are presented : possibilities of indirect selection for feed efficiency of laying hens corrected for body weight and egg production; selection plateaux for egg laying and possible utilization of a heterozygote advantage at locus $H i$; selection to lower percentage of broken eggs in cages and possible use of $d w$ and $O$ genes.

\section{INTRODUCTION}

The idea of utilising known genes in selection is, of course, nothing new. However, in general qualitative visible traits are involved, and breeders are not accustomed to include single genes to modify production criteria in their breeding plans.

It may be suggested, in particular cases, that the genotype to specified loci be included in selection indexes. This can sometimes be an appreciable aid to selection. The aim of this paper is to present a few examples in favor of this idea. 


\section{GENERALITIES ON INDIRECT SELECTION}

\section{AND GENE UTILIZATION}

In what conditions is it worth considering specified genes in breeding programs? Common sense suggests that it will be the more useful as it will concern a trait difficult to improve by direct selection, and as the specified gene (s) will have a larger effect on this trait. This has been studied on a theoretical basis by SMITH (I967).

The use of Mendelian factors may be regarded as a particular case of "indirect " selection : selection on a trait $B$ (genotype at a particular locus) to improve a trait A. Such selection will not only be useful but necessary, if direct selection produces a genetic gain per generation $\Delta \mathrm{G}_{\mathrm{A}}=0$.

$$
\text { as } \Delta \mathrm{G}_{\mathrm{A}}=\bar{\imath} \cdot h_{\mathrm{A}}^{2}
$$

$\bar{\imath}:$ selection intensity,

$h_{\mathrm{A}}^{2}$ : heritability of trait A,

this will be the case if :

a) The selection intensity exerted on $\mathrm{A}$ is equal to zero or $b$ ) if the heritability of $\mathrm{A}$ is zero.

The first table summarizes several corresponding possibilities.

TABLE I

Cases of indirect selection (including single genes) being necessary or useful

\begin{tabular}{|c|c|}
\hline Reasons for use of indirect selection & Examples \\
\hline (a) $\bar{\imath}=0$ (no selection intensity) & \\
\hline$\left(a_{1}\right)$ Selection in one sex only & - egg-laying traits \\
\hline$\left(a_{2}\right)$ Trait costly and/or difficult to measure & $\begin{array}{l}\text { - feed efficiency of laying } \\
\text { hens } \\
\text { - volume of droppings }\end{array}$ \\
\hline $\begin{array}{l}\left(a_{3}\right) \text { Environment costly and/or difficult to } \\
\text { realize }\end{array}$ & $\begin{array}{l}\text { - resistance to specific di- } \\
\text { seases } \\
\text { - adaptation to " exotic " } \\
\text { climates (e.g. heat). }\end{array}$ \\
\hline $\begin{array}{l}\left(a_{4}\right) \text { Presence of unfavourable genetic corre- } \\
\text { lations }\end{array}$ & $\begin{array}{l}\text { - Fast chick growth and } \\
\text { feed efficiency of dam }\end{array}$ \\
\hline $\begin{array}{l}\text { (b) } \bar{i} \neq 0, h^{2}=0 \\
\text { non-additivity of remaining genetic va- } \\
\text { riance (e.g. overdominance) }\end{array}$ & - laying intensity \\
\hline $\begin{array}{l}\text { (c) } \bar{\imath} \neq 0, h^{2} \neq 0 \\
\text { (Discussion by SмIтн, } 1967 \text { for the case } \\
\text { of single genes) }\end{array}$ & - Shell strength \\
\hline
\end{tabular}


$a_{1}$ ) A trait may be expressed in only one sex (e.g. females). Then, individual selection on males has to be made using indirect criteria. Among these might figure specified genes, but as there are other possibilities (selection on performances of sisters, daughters...) the advantage of the former is subject to discussion in each particular case.

$a_{2}$ ) A more convincing case is that of traits for which direct selection (in both sexes) is too difficult or too costly. For instance, a selection on feed efficiency of laying hens, independent of body weight and egg production, requires controlling feed consumption on an individual, or at least on a family, basis ; this control is costly in time and money. Another case would be that of a breeder attempting to reduce the volume of droppings produced by caged birds.

$\left.a_{3}\right)$ In the previous case, the measurement of the trait was difficult or costly to obtain; also the environment where a genetic improvement is desired may be difficult to realize ; for instance, in selection for resistance to a specific disease because of the cost and risks of exposure, or for adaptation to environmental conditions difficult to realize on a large scale in our countries : Tropical climate, feed including local ingredients, and so on.

In these various situations, a selection on males only may be made. This would reduce cost, but research of indirect criteria may be more satisfactory.

$a_{4}$ ) A case where the reaiized selection intensity on a trait A may be practically zero is when $\mathrm{A}$ has a negative genetic correlation with an economically interesting trait $B$, so that a selection in favor of both $A$ and $B$ in each generation gives no progress for either. A possible issue is the research of indirect criteria correlated with $\mathrm{A}$ but not presenting the unfavorable correlation with $\mathrm{B}$, for instance, single genes having an effect not consistent with overall correlation.

b) The second case where indirect selection is necessary is when $h_{\mathrm{A}}^{2}=0$ ("Selection plateaux $)$.

A selection is exerted, but there is no corresponding gain, either because the genetic variability for the trait is exhausted in the population, or because the additive variance alone is suppressed (for instance, unfixed genes with heterozygote advantage may remain). In these two cases, single genes may be of some utility, especially in the former, as the only solution is to introduce a new genetic variability, the controlled introduction of specified genes minimizing the contribution from extraneous genomes.

To these situations we can add that $(c)$ of traits with low, but not zero, heritability for which the question of indirect selection may also be settled.

In presence of one of these favorable cases, it is not only necessary to have at hand genes with an appreciable effect on the trait to improve, but these genes must be sufficiently easy to detect. An ideal case is that of genes " marked " by a visible effect, but the frequency of significant associations between such genes and quantitative traits is limited a priori and often these genes are fixed in commercial strains. The case of blood groups presents another difficulty, especially for locus $B$ alleles, because even if they have an appreciable incidence on production traits, their identification is cumbersome and more or less limited to a particular population. Certain genes responsible for biochemical polymorphisms may be easier to deal with, although they are somewhat more costly to detect. 
Finally, it is preferable to handle genes having a known mode of action (at least up to a certain level), for in this case the existence and generality of their possible pleiotropic effects can be more positively proven.

\section{SOME EXAMPLES OF INDIRECT SELECTION \\ AND UTILIZATION OF SINGLE GENES}

A few examples will be evoked in this paper, with particular reference to our results at Jouy en Josas. Table 2 summarizes a list of these, reviewing the traits already mentioned on the right of table $I$.

TABLE 2

Suggested possibilities of indirect selection

\begin{tabular}{|c|c|c|}
\hline \multirow{2}{*}{ Trait to improve } & \multicolumn{2}{|c|}{ Possible indirect selection } \\
\hline & quantitative trait(s) & mendelian gene (s) \\
\hline $\begin{array}{l}\text { Feed efficiency of laying } \\
\text { hens }\left(a_{2}\right)\end{array}$ & $\begin{array}{l}\text { - body size } \\
\text { - adult weight gain } \\
\text { - short term records } \\
\text { of feed consumption } \\
\text { - size of unfeathered } \\
\text { appendages }\end{array}$ & $\begin{array}{l}d w \\
\text { genes reducing this size } \\
: P \text { ? }\end{array}$ \\
\hline $\begin{array}{l}\text { Volume of droppings } \\
\left(a_{2}\right)\end{array}$ & & $\begin{array}{l}\text { "polydipsia (normal } \\
\text { allele) }\end{array}$ \\
\hline $\begin{array}{l}\text { Resistance to specific } \\
\text { diseases }\left(a_{3}\right)\end{array}$ & $\begin{array}{l}\text { - body temperature } \\
\text { for resistance to } \\
\text { pullorum (1) } \\
\text { - immune response? }\end{array}$ & 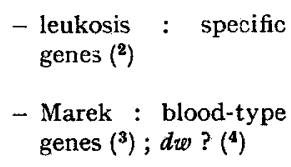 \\
\hline $\begin{array}{l}\text { Shell strength }(c) \text {, possi- } \\
\text { bly with reference to } \\
\text { adaptation to heat }\left(a_{2}\right)\end{array}$ & $\begin{array}{l}\text { - shelle strength in } \\
\text { temperate climate } \\
\text { - measures of thermal } \\
\text { stress }\end{array}$ & $\begin{array}{l}-O \text { (blue egg) } \\
-d w\end{array}$ \\
\hline $\begin{array}{l}\text { Fast chick growth }+ \\
\text { dam feed efficiency } \\
\left(a_{3}\right)\end{array}$ & & - dw (broiler dam) \\
\hline Laying intensity $(b)$ & $\begin{array}{l}\text { - more " physiologi- } \\
\text { cal " criteria? }\end{array}$ & $\begin{array}{l}\text { - } H i \text { (lectin-detected } \\
\text { antigen) } \\
\text { - Blood-type locus } B\left({ }^{5}\right) \\
\text { - other serological or } \\
\text { biochemical markers }\end{array}$ \\
\hline $\begin{array}{l}\text { (1) Hutt and Crawf } \\
\left({ }^{2}\right) \text { CRittenden (196 } \\
\left({ }^{3}\right) \text { Gilmour (1969), } \\
\text { (4) Meurier and Mé } \\
\text { (5) Briles (1960), Gi }\end{array}$ & $\begin{array}{l}\text { ORD }(1960) . \\
8) \text {. } \\
\text { JOHNSON (1973). } \\
\text { RAT (1972). } \\
\text { LMOUR }(1960) .\end{array}$ & \\
\hline
\end{tabular}


Referring back to the nomenclature of table $r$. the first two traits, feed efficiency, volume of droppings, correspond to situation $\left(a_{2}\right):$ traits costly and/or difficult to measure. Only the former will be dealt with here, including an association of " marker " genes with feed intake of laying hens.

Resistance to specific disease corresponds typically to case $\left(a_{3}\right)$ (difficult environment to realize). It is beyond the scope of this paper to discuss this problem.

Some of our results concern single-gene effects on egg-shell breakage in cages. This represents situation $(c)$; it might also be viewed as an attempt of indirect selection to improve shell strength at higer ambient temperatures, which corresponds to case $\left(a_{3}\right)$.

As regards case $\left(a_{4}\right)$ (unfavorable genetic correlations), an example is the situation of broiler breeders making efforts to improve feed efficiency and reproductive capacity in maternal lines while continuing to increase broiler growth rate. The unfavorable correlation is between a higher growth rate on one hand, larger adult size and higher feed requirements of the dam on the other. Selection for a modified growth curve may be conceived (e.g. RICARD, in press) but, as a single-gene effect, the use of the sex-linked dwarf is to be mentioned.

Finally, for laying intensity, subject to selection "plateaux" (case $b$ ) the problem of the $H i$ gene (responsible for an agglutination reaction of red-blood cells) will be discussed.

Indirect selection, single genes and feed efficiency of laying hens

Following BYERLY (I94I) and other authors, one can express feed consumption in a given time by a multiple regression equation of the form :

$$
\mathrm{F}=a \mathrm{~W}^{\alpha}+b \Delta \mathrm{W}+c \mathrm{E}+\mathrm{R}
$$

where $\mathrm{F}=$ observed feed intake of an individual hen,

$\mathrm{W}=$ mean body weight during the period of observation,

$\Delta \mathrm{W}=$ body weight variation,

$\mathrm{E}=$ total weight of eggs produced,

$\mathrm{R}=$ " residual " term (deviation of observed feed intake from the expected value given by the regression),

$a, b, c=$ appropriate coefficients.

The exponent $\alpha$ is generally of the order .6-.7 (In our own results, taking .5 is a sufficient approximation).

Of course, the first factor to be taken account of is body weight (W) ; it is well known that reducing size of laying hens by breeding improves feed efficiency. As concerns single genes, the dwarf gene $d w$ is one of the possible contributions to further progress in this direction.

But even with equal body weight there remain differences in feed efficiency which may not be negligeable. In our experimental strains in Jouy en Josas ( $\left.{ }^{1}\right)$, we observed significant " residual » differences in feed intake ( $R$ » variable) between families of half-sisters. The average difference between particular families can

( $\left.{ }^{1}\right)$ Including a synthetic strain with normal $(D w)$ and dwarf (dw) birds, and a strain of RhodeIsland red. 
represent more than Io p. Ioo of mean feed consumption in the flock (BoRDAS, MÉrat, I974).

To improve this " residual " feed efficiency, we investigated the possibility of selecting on the $\mathrm{R}$ variable estimated by short-term measurement (two weeks) of feed consumption (BORDAs, MÉRAT, I975). The results show a rather high correlation of +.84 between individual feed consumption estimated on a short-term and on a longer-term ( 3 months) basis. This remains true after correcting for average body weight and egg production during the " long " period of observation $(r=+.7 \mathrm{I})$.

However, the individual measurement of feed intake, even over a relatively short period, may be difficult. So, we looked for possible correlations between " residual " consumption and both production traits and body measurements of the same bird.

Three correlations appear significant on the whole in our data from I967 to I974 (BORDAS, MÉrAT, 1974). These correlations are with water intake (of the order of +.3$)$, wattle length $(+$. . I $)$ and shank length $(+$. I3).

The correlation with water intake suggests limited possibility of improving feed efficiency by reducing the former, if this correlation exists at the genetic level. A very rough evaluation of water consumption may be obtained by visual scoring of the consistency of droppings. This could at least apply to the detection of the " polydipsia "gene (Dunson and Buss, I968), but this case of excessive drinking may be a special one. Generally speaking our own un published data show no more correlation between water intake and " residual " feed consumption at fixed total feed intake, which would not suggest the former to be associated with modified metabolic efficiency.

With wattle length and shank length, the phenotypic regression coefficients of " residual "feed intake correspond, respectively, to an increase of IIo $\mathrm{g}$ of feed consumed per 28 days for wattles I $\mathrm{cm}$ longer, and of the same order per additional $\mathrm{cm}$ for shank length. Any significant relation between these measurements and uncontrolled feed wastage seems to be excluded in our conditions, but as a simple explanation, it may be suggested that heat dissipation increases due to larger unfeathered appendages (STURKIE, I965, evaluates at I5 p. IOo the proportion of heat lost through only comb and wattles). Our results may thus suggest other indirect selection to improve feed efficiency by reducing the size of these organs.

Several major genes for wattle and comb size are known. For instance, it is considerably reduced by the $\mathrm{P}$ (pea comb) gene. Preliminary data on " residual " feed consumption of $P p$ and $p p$ hens also suggest, that the pea-comb allele causes a slight reduction (between $I .5$ and 2 p. roo) of this trait.

Another interesting correlated trait does not concern $\mathrm{R}$ (residual feed consumption) but a variable $R^{\prime}$ defined as the deviation of observed consumption from its expectation given by a regression equation including body weight $(W)$ and egg mass produced (E), but not weight variation $\Delta \mathrm{W}$.

This variable is correlated with $\Delta \mathrm{W}$ which is very simple to measure. The observed regression of $\mathrm{R}^{\prime}$ on $\Delta \mathrm{W}$ shows that a reduction of about 50 gms for $\Delta \mathrm{W}$ per 28 days should lead to a decrease of about roo gms of feed consumed during the same period, again if the "genetic " regression is comparable to the phenotypic one (unpblished data). 
Another single gene effect, at first sight differing from previous cases, concerns several plumage color genes.

Comparing full sisters of different genotype at such loci, in our " synthetic " population, we observed repeatedly a slightly but significantly lower " residual " feed consumption for white laying hens than for their colored sisters. This was obtained in two trials for $c c$ hens (recessive white) compared to $C c$ ones, in two others for $I i$ birds (dominant white) compared to ii (MÉRAT, I968; MÉRAT, BoRDAS, I97I). A non-significant result on fewer data concerns $e e$ hens (restricted black) which show a slightly lower $\mathrm{R}$ value than their $E e$ (extended black) sisters (unpublished data). In each case, the average initial body weight and egg production did not appreciably differ for the compared genotypes.

This seemingly parallel effect for 3 independent loci suggested the hypothesis of a pleiotropic effect associated with plumage color. Nothing suggests any difference in digestive and metabolic efficiency, nor in behaviour (energy spent in activity). No difference in internal temperature was found. On the other hand, we tried to test the hypothesis of differences in heat dissipation through the plumage. Results of radiation measurement were not easy to interpret (anyway, a direct relation between visible pigmentation and infra-red radiation can hardly be expected). However, two other observations, concerning the I gene may be of interest.

I. Preliminary data suggest a higher average total weight of the plumage for white hens ( $i$ vs $i i)$.

2. After 5-6 months of laying, the frequency of featherless zones was found to be significantly higher for $i i$ than for $I i$ counterparts (MÉRAT and BorDAs, unpublished data).

Thus a tentative explanation of our results for feed efficiency would be that white hens have a more insulating feather coverage than colored hens. We plan to check this hypothesis further, and to extend our observations to the $S / s$ locus.

It will be of some general interest to see if the quantity and distribution of plumage (not including rather obvious cases such as $\mathrm{Na}$ or scaleless genes) has a significant bearing on feed efficiency in our conditions. Of course, an evaluation of plumage weight is not practical at all, but scoring for " naked " areas in the plumage after some months in production may be.

Finally, another single gene effect is in relation to short-term regulation of feed intake (BORDAS, MÉRAT, in press). For the last years we recorded individual daily feed intake for 2 week periods. This gives an estimation of feed ingested by each bird on days with or without egg formation and oviposition, with 4 types of days represented by $\mathrm{X}=$ days without either egg formation or oviposition, $\mathrm{L}=$ days with oviposition only, $\mathrm{O}=$ with egg formation only, $\mathrm{LD}=$ with both egg formation and oviposition (using the symbols proposed by WooD-Gush, HoRNe, r970). Normal $(D w)$ and dwarf $(d w)$ hens are compared. In percentage, and even in absolute value, the difference between days with and without egg formation is higher for dwarf hens. A proposed hypothesis is that dwarf hens, having smaller skeletal reserves, have to draw from their feed a larger part of the calcium needed for egg shell formation. A closer correlation found for genotype $d w$ between feed intake and shell thickness of the egg being formed also seems to favorize this hypothesis. If so, and if the use of dwarf laying hens is more widespread in the future, a question to be asked is 
would these hens benefit more than normal ones from separate calcium intake, such as proposed by MONGIN, SAUVEUR (r974), for shell strength, and/or bone accidents in cages?

\section{Laying intensity : association with a single gene (Hi)}

In line with the problem of selection plateaux for laying (CLAyToN, I968), we were interested in a consistent advantage for laying intensity, that we observed, associated with the heterozygous state at a two-allele locus easy to detect, the $\mathrm{Hi}$ locus (Scheinberg, RECKEL, I96I). The dominant allele ( $\mathrm{Hi}$ ) causes an agglutination of red blood cells with certain seed extracts. This reaction is limited to laying hens, for it requires sufficient oestrogen concentration in the plasma. It is absent in hihi birds. The $H i$ locus seems to be very frequently polymorphic according to samplings made in various populations by SCHEINBERG, RECKEL (I96I), BOREL (I964), ERDös (I969) and by our own laboratory.

Since I966 the performance of $H i h i$ and $h i h i$ birds has been compared every year in our " synthetic" strain at Jouy on pairs of full sisters. Hi Hi and Hi hi were compared on mean performance in families with a different expected proportion of these two genotypes among birds of the ( $\mathrm{Hi}$ ) phenotype (MÉRAT, DURAND, r973).

It appears from our data that the number of eggs laid - at least during our period of control, including about the first half of the laying year - is higher for $H i h i$ females than for the other genotypes. The superiority of $H i h i$ birds over $h i h i$ ones is of the order of $9 \mathrm{p}$. Ioo of the mean population, but the most inferior genotype is $\mathrm{HiHi}$, with an estimated reduction in average egg number (as compared to the mean of the $H i$ hi birds) of the order of $25 \mathrm{p}$. IOO, which is surprisingly high.

The observed effect on egg number cannot be explained by a difference in age at first egg. We wondered if "intensity " or " pauses ", in Goodale's sense, was more likely to play a role (HUTT, I949). For convenience we considered as " pauses " any interruption of laying for more than 2 consecutive days ; "intensity " is the ratio of egg number to the number of control days after deduction of " pauses ". We found no significant difference between genotypes at the $H i$ locus for " intensity ". On the contrary " pause " days are minimal for the $H i$ hi genotype (Mérat and Durand, in press).

Finally, it may be concluded that our population possesses one chromosomal region with heterozygote advantage for egg number, and especially for the absence of " pause ". Whether this is a pleiotropic effect of the Hi gene remains open to question. It cannot be excluded, as we found very comparable results (significant heterozygote superiority for egg number) on 2 generations, in two other populations at the Poultry Research Centre in Nouzilly (MÉRAT and DURAND, in press). One population had some common, although remote origin with ours, the other did not. On the other hand, some indication of the physiological effect of the $H i$ allele and its possible relation with estrogen binding in plasma (SCHEINBERG, I97I) suggests a direction of research for better understanding of possible side-effects.

It would be interesting to isolate genes or groups of linked genes with a special effect on " pauses ", for we have very little knowledge of their genetic and physiological determination. By comparison, we observed that the $d w$ gene, which reduces egg production in light strains, mainly effects mean.clutch length, and has rather little effect on "pauses " (table 3). 


\section{Percentage of broken eggs : effect of dw and $O$ genes}

Broken eggs in cages are an important economic problem; CARTER (I970) discussed various aspects of this problem, including some genetic ones. It seems important to investigate further which other traits of economic value are correlated with per cent of broken eggs. As an illustration, we found (SILBER and MÉRAT, I974) three main correlations for this trait in our flock : -.27 with shell thickness, +.35 with body weight, $+.3 I$ with egg weight.

The correlation with egg shell thickness is easy to understand. With more recent data we found a correlation of comparable magnitude with elastic deformation under a $500 \mathrm{~g}$ load (ScHOORL, BOERSMA, I962), in concordance with previous results in the literature (CARTER, I970). On the other hand, the appreciable correlation with adult weight within our population may be due to weight "per se ", as CARTER (I970) showed that different weights applied to cage floors cause differences in breakage by modifying the rigidity of the floor. Finally, the correlation of egg weight with egg breakage was found also by Bogol,YUBSKII and TSARENKo (I973) but not by ANDERSON et al. (1970). This divergence might possibly result from experimental conditions, including the relative values of the egg mass and the fraction of the floor mass which is involved in the expression of its kinetic energy.

Direct selection on shell breakage, or correlative selection on shell deformation and thickness, are quite possible.

TABLE 3

Effects associated with the dw gene in an experimental population

\begin{tabular}{|c|c|c|c|}
\hline \multirow{2}{*}{ Trait } & \multicolumn{2}{|c|}{ Mean value } & \multirow{2}{*}{ Significance } \\
\hline & $D w$ & $d w$ & \\
\hline $\begin{array}{c}\text { Body weight of females at } 11 \\
\text { months }(g) \ldots \ldots \ldots \ldots \ldots \ldots \ldots\end{array}$ & 2366 & 1623 & $* * *$ \\
\hline Laying percentage $(\mathbf{1}) \ldots \ldots \ldots \ldots$ & 72.7 & 60.9 & $* * *$ \\
\hline Laying percentage (pauses deduced) & 79.1 & 67.2 & $* * *$ \\
\hline Days of pauses $(\%) \ldots \ldots \ldots \ldots$ & 8.3 & 10.9 & $*$ \\
\hline Mean egg weight at 10 months $(g) \ldots$ & 54.8 & 51.0 & *** \\
\hline Shell thickness $(1 / 100 \mathrm{~mm}) \ldots \ldots \ldots$ & 35.4 & 34.8 & NS \\
\hline Broken eggs $(\%) \ldots \ldots \ldots \ldots \ldots$ & 13.7 & 5.8 & $* * *$ \\
\hline Deformation $(\mu) \ldots \ldots \ldots \ldots$ & 26.2 & 25.3 & NS \\
\hline Soft-Shelled eggs $(\%) \ldots \ldots \ldots \ldots$ & 2.8 & .3 & $* * *$ \\
\hline $\begin{array}{l}\text { Mortality by Marek disease after } \\
\text { inoculation }(\%)\left({ }^{2}\right) \ldots \ldots \ldots \ldots \ldots\end{array}$ & 45.3 & 27.2 & $* * *$ \\
\hline
\end{tabular}

(1) No difference in heavy strains.

(2) Two tests giving a comparable result.

However, in this respect, it may be of interest fo mention two important singlegene effects.

One concerns the sex-linked dwarf gene $d w$. Dwarf hens in our conditions have less than half the $p$. roo of broken eggs which may be attributed to normal size 
hens of similar origin. Table 3 mentions this (among other traits). RICARD, CochEZ (I972) found similar results in a heavier strain.

As table 3 suggests, this is not a matter of shell thickness (which shows no significant difference), nor is it due to intrinsic shell strength as estimated by shell deformation (making allowance for the difference in size between eggs from $D w$ end $d w$ hens). However, there may be two simple reasons, both concerning " mechanical injury " caused to the egg :

- a possibly lower mean height of drop at oviposition of dwarfs which have shorter shanks and different attitude ;

- a direct effect of body weight, which concords with the general correlation observed within " normal " hens.

This represents an additional reason in favour of the use of dwarf laying hens, when considering their advantages and disadvantages (summarized, in table 3). It would also hold for broiler dams, if they reproduce in cages in the future ;

- a second gene found to have a bearing on egg breakage is the "blue egg " gene $O$. It was introduced in part of our flock about ro years ago. SilbER and MÉRAT (I974), compared p. IOo of breakage for $O o$ and oo full sisters in cages. The results are consistent, showing, that blue eggs have half the breakage per cent, compared to normal-coloured eggs. On the other hand, no significant difference was found associated with this gene for growth, body weight at any age, laying performance, egg weight, albumen height and shell thickness. Conversely, deformation is significantly lower for blue eggs. Explanation of the reduced incidence of breakage is symmetrical to that for the dwarf gene. There does not seem to be any effect associated to the $O$ gene for " mechanical injury " caused to the egg, but rather a difference in intrinsic shell strength. It is premature to hypothesize on wheter the blue pigment (biliverdin) affects shell texture, is accompanied by differences in the protein matrix of the shell, or whether there is also a difference in the cuticle and/or in the membrane. Preliminary observations would suggest that blue egg shell membrane is thicker.

From a practical point of view, the incorporation of the $O$ gene in egg laying strains in our market conditions seems problematic, even if at first sight, it has no deleterious effect on performance. But two possibilities may be worth further exploration :

- First, introduction of this gene in female broiler strains, if reproduction in cages becomes a current practice in the future.

- Second, possible incorporation into egg laying strains intended for hot climates, since some markets may have no a priori objection to blue shells, and shell is expected to be more of a problem at high ambiant temperature. Moreover, preliminary data obtained in climatic rooms suggest that hens with the $O$ gene are less affected than others in regard to reduction of shell thickness at high temperatures.

\section{CONCLUSION}

These few examples may illustrate the way in which single genes may sometimes bring forth a peculiarity of economic significance. Of course, this is only part of the 
picture, especially when the desired allele(s) is not present in the commercial populations. Introduction of foreign germ plasm is a serious problem for the commercial breeder and in this sense, the use of individual genes in breeding represents a narrow approach. This is why the examples proposed are preferably in cases where direct selection is not possible or easy.

At the research level, single genes however present an additional advantage, for the investigation of their possible associations to quantitative traits requires facilities which are not comparable to those used by large breeders in creating commercial strains and crosses. This is one way in which geneticists can hope to bring, not only ideas, but sometimes a little genetic material for practical breeding. This is especially true in problems of local adaptation which the commercial breeder may not find sufficiently rewarding, although they may be important for the development of poultry production in particular areas.

Reçu pour publication en décembre 1975.

\section{RÉSUMÉ}

\section{SÉLECTION INDIRECTE CHEZ LA POULE AVEC UNE ATTENTION SPÉCIALE POUR CERTAINS GÈNES PRIS INDIVIDUELLEMENT}

L'intérêt d'une sélection indirecte en aviculture est discuté, en particulier quant à l'utilisation de gènes connus. Les situations les plus favorables sont celles où l'intensité d'une sélection directe est nulle (caractère impossible ou trop cớteux ·à mesurer, environnement où le progrès est désiré difficile à réaliser, ou présence de corrélations génétiques négatives annulant le gain génétique) et celle où l'héritabilité du caractère à améliorer est faible ou nulle (" plateaux " de sélection).

Des exemples correspondant à ces situations sont présentés : possibilités de sélection indirecte pour l'efficacité alimentaire des poules pondeuses compte tenu du poids corporel et de la ponte; " plateau " de sélection pour la production d'œufs et utilisation éventuelle d'un avantage hétérózygote au locus $\mathrm{Hi}$; sélection pour diminuer le pourcentage d'œufs cassés en cages et utilisation possible des gènes $d w$ et $O$.

\section{REFERENCES}

Anderson G. B., Carter T. C., Morley R. J., I97o. Some factors affecting dynamic fracture of egg shells in battery cages. In : Factors affecting egg grading, B.E.M.B. Symposium nº 6 (Ed. E. M. Freeman, R.F. Gordon), 53-69.

Bogolyubski S. I.; Tsarenko P. P., 1973. [Ways of decreasing egg breakage] abst. Scient. Poult. Conf. Vologda, 57-59.

Bordas A., MÉrat P., r975. Enregistrement sur une courte période de la consommation d'aliment chez la poule pondeuse pour l'étude génétique de l'efficacité alimentaire. Ann. Génét. Sél, anim. (sous presse).

Bordas A., Mérat P., r976. Effect of laying on food or water intake in dwarf or normal fowls. Brit. Poult. Sci. (in press).

Bordas A., MÉrat P., r974. Variabilité génétique et corrélations phénotypiques caractérisant la consommation alimentaire de poules pondeuses après correction pour le poids corporel et la ponte. Ann. Génét. Sél. anim., 6, 369-379.

BoREL F., I964. Recherches immunogenétiques sur des substances spécifiques de groupe chez la Poule et sur leur utilisation comme marqueurs de gènes dans l'élevage. Thesis, Univ. Zürich. 
Briles W. E., I96o. Blood groups in chickens, their nature and utilization. World Poult. Sci. J., 16, 223-242.

Byerly T. C., I94x. Feeds and other costs of producing market eggs. Univ. Maryland agric. exp. sta., $\mathrm{n}^{\circ} \mathrm{A}$.

Carter T. C., I97o. Why do egg shells crack? World Poult. Sci. J., 26, 549-56r.

Clayton G. A., r968. Some implications of selection results in poultry. World Poult. Sci. J., 24, 36-57.

Crittenden L. V., i968. Avian tumor viruses. Prospects for control. IVorld Poult. Sci. J., 24, I8-35.

Dunson W. A., Buss E. G., 1968. Abnormal water balance in a mutant strain of chicken. Sci., 161, I67-I69.

ERDöS A., I969. Untersuchungen mit phytoagglutininen bei Inzucht hühnern. Bhut, 19, $559-563$.

Gilmour D. G., 196o. Blood groups in chickens. Brit. Poult. Sci., 1, 75-roo.

Gilmour D. G., r969. Blood group research in chickens. Agric. Sci. Rev., 7, 13-22.

HutT F. B., 1949. Genetics of the fowl. McGraw HrLl, N. Y.,

Hutt F. B., CRAwford R. D., 1960. On breeding chicks resistant to pullorum disease without exposure thereto. Can. J. Genet. and Cytol., 21, 357-370.

Johnson L. W., r973. Variation of life span in an inbred line caused by B blood antigen alleles. Poult. Sci., 52, 2045 (abstr.).

Mérat P., r968. Consommation alimentaire de pondeuses $C c$ et $c c$. Ann. Zootech., 17, 337-339.

Merat P., Bordas A., I971. Consommation alimentaire de pondeuses blanches (Ii) et colorées (ii). Ann. Génét. Sél. anim., 4, 375-384.

Mérat P., Durand L., I973. Avantage lié au génotype Hihi pour l'intensité de ponte chez la Poule. Ann. Génét. Sél. anim., 5, 469-476.

Mérat P., Durand L. Association du gène $H i$ avec la production d'œufs. Nouveaux résultats, concernant particulièrement l'intensité de ponte et les " pauses". Ann. Génét. Sél. anim. (in press).

Meurier C., Mérat P., I972. Résistance de certains génotypes à la maladie de Marek chez la Poule. II. Influence possible du gène de nanisme dw. Ann. génét. Sél., anim., 4, 4I-43.

Mongin P., Sauveur B., 1975. Alimentation calcique séparée des pondeuses. Le courrier avicole june 1975 .

Nordskog A. W., French A. Jr, Arboleda C. R., Casey D. IV., 1972. Breeding for efficiency of egg production. World Poult. Sci. J., 29, 175-I88.

RAPP K. G., I970. Die wirtschaftlichkeit einer zwerg mutante der weissen Leghorn in der Linien-und Hybrid zucht. Thesis, Univ. Göttingen.

RICARD F. H. (in press).

Ricard F. H., Cochez L. P., I972. Le gène de nanisme $d w$ et les performances des poules dans une souche de type femelle chair. Ann. Génét. Sél. anim., 4, 297-303.

Scheinberg S. L., Reckel R. P., r96r. Detection of red cell agglutinogens with lectins in chickens. Poult. Sci., 40, 689-698.

ScheINBERG; S. L., I97I. The $h i$ agglutinogen of chickens : Basis for cell transformations. $J$. Exp. Zool., 177, 455-462.

Schoord P., Boersma H. Y., I962. Research on the quality of the egg shell. A new method of determination. I2th World Poult. Cong., Sydney, 432-435.

Silber J., Merat P., r974. Étude génétique de la coloration bleue de la coquille des œufs chez la Poule : comparaison des performances des animaux Oo et oo. Ann. Génét. Sél. anim., 6, 405-4r4.

Sмrтн C., I967. Improvement of metric traits through specific genetic loci. Anim. Prod., 9, 349"358.

Sturkie P. D., 1965. Avian Physiology, 2nd ed. Cornell Univ. Press.

Wood-Gush D. G. M., Horne A. R., r97o. The effect of egg formation and laying on the food and water intake of Brown Leghorn hens. Brit. Poult. Sci., 11, 459-466. 